teoreticheskie problemy psihologi [Methodological and theoretical problems of psychologists]. Moscow, $445 \mathrm{p}$. [in Russian].

7. Malykhin, O. (2009). Orhanizatsiia samostiinoi navchalnoi diialnosti studentiv vyshchykh pedahohichnykh navchalnykh zakladiv : teoretykometodolohichnyi aspekt : monohrafiia [Organization of independent educational activity of students of higher pedagogical educational institutions: theoretical and methodological aspect: monograph]. Kryvyi Rih, 307 p. [in Ukrainian].

8. Pidkasistyj, P. (Ed.). (1998). Pedagogika: ucheb. posobie dlya stud. [Pedagogy: textbook for students]. Moscow: Pedagogical Society of Russia. [in Russian].

9. Sadova, V. V. (2016). Fundamentalizatsiia zmistu pedahohichnykh dystsyplin u pidhotovtsi maibutnikh uchyteliv pochatkovoi shkoly: teoretykometodolohichni aspekty [Fundamentalization of the content of pedagogical disciplines in the preparation of future teachers of elementary school: theoretical and methodological aspects]. Kryvyi Rih, 392 p. [in Ukrainian].

10. Fitsula, M. (2010). Pedahohika vyshchoi shkoly: navch. posib. [Pedagogy of the Higher School: textbook]. Kyiv, 456 p. [in Ukrainian].

Стаття надійшла до редакції 11.03.2019

УДК 005:502/504+378:005-057.212

DOI:

Лілія Чайка-Петегирич, кандидат економічних наук, доиент кафедри економіки та менеджменту

Дрогобицького державного педагогічного університету імені Івана Франка

\title{
ЕКОЛОГІЧНИЙ МЕНЕДЖМЕНТ В СИСТЕМІ ФАХОВОЇ ПІДГОТОВКИ МАЙБУТНІХ МЕНЕДЖЕРІВ
}

Статтю присвячено проблемі екологічної освіти майбутніх менеджерів. В умовах сталого (збалансованого) розвитку ключовим завданням $\epsilon$ збереження якості навколишнього природного середовища і раціональне використання природних ресурсів. Тому необхідним в сучасних умовах $\epsilon$ уміння приймати екологічно відповідальні рімення, передбачати наслідки діяльності, пов'язаної $з$ довкіллям та природокористуванням. У статті акиентовано на підготовиі майбутніх фахівиів до застосування принципів, методів екологічного менеджменту, який орієнтований на вимоги сталого розвитку.

Ключові слова: сталий розвиток; природні ресурси; екологічна освіта; екологічні знання; екологічний менеджмент; фахова підготовка.

Jim. 8.

Liliya Chayka-Petehyrych, Ph.D.(Economics), Assosiate Professor of the Economics and Management Department Drohobych Ivan Franko State Pedagogical University

\section{ENVIRONMENTAL MANAGEMENT IN THE SYSTEM OF SPECIALIZED TRAINING OF FUTURE MANAGERS}

The objective of sustainable (balanced) development is to ensure the dynamic socio-economic growth, preservation of the quality of the natural environment and the rational use of natural resource potential. The concept of sustainable development determines the transition from the scientific outlook to the ecological outlook, which is a prerequisite for the transition from a modern industrial and consumer society to a society of sustainable development. The article mentions the necessity of formation of ecological culture of students, managers of environmental values in the system "nature-man-society". Among these values is the ability to take ecologically responsible decisions, to predict the consequences of activities related to the restructuring of the environment and nature managements, to combine their own vital interests with the present and future social and natural environment.

World experience proves that the state of preservation of the environment and the rational use of natural resources, the efficiency of production is directly depended on the development of education, the improvement of education technologies and raising the ecological and economic education level of the population. Therefore, the article is devoted to the issues of preparing future managers for environmental justifiable activities in the professional field. It was determined that the course "Environmental Management" was aimed at forming ecological knowledge, ecological consciousness and culture of future managers. In the modern sense, environmental management studies management relationships in the organizations that ensure its sustainable development, environmental protection, human life safety, rational use of natural resources and environmental safety, aimed at the implementation of 
environmental goals and programs of environmental impact, and also forms the knowledge of the environmental strategies for community development, nature management and nature conservation.

Keywords: sustainable development; natural resources; an environmental education; ecological knowledge; an environmental management; specialized training.

П остановка проблеми. В умовах сучасної екологічної ситуації забезпечення сталого соціальноекономічного розвитку неможливе без збереження та охорони довкілля, без дотримання вимог екологічної безпеки раціонального природокористування. Враховуючи вимоги сталого розвитку, актуальним $\epsilon$ впровадження системи екологічного менеджменту у сферу природокористування, включення екологічної складової увиробничий та персональний менеджмент, в фінансовий менеджмент та менеджмент логістики.

“Система екоменеджменту спрямована на зміну сучасного соціально-економічного розвитку в абсолютно новому напрямку екологічної політики та створення передумов для функціонування моделі сталого та екологобезпечного розвитку. Вона відкриває нові можливості та сприяє своєчасному забезпеченню природними ресурсами, інноваційному процесові i отриманню прибутку від підвищення ефективності управлінської діяльності” [6, 88].

У розвитку і поширенні системи екологічного менеджменту велика роль належить екологічній освіті, яка має на меті формування у майбутніх фахівців екологічних знань, екологічної культури та світогляду, спеціальну підготовку менеджерів до екологічного аналізу діяльності структурних підрозділів підприємства чи організації, до здійснення внутрішнього екологічного аудиту.

Аналіз основних досліджень і публікацій. У контексті нашого дослідження значимими є наукові праці, присвячені теоретичним аспектам екологічної освіти (Т. Іванова, Т. Лукашенко, Л. Лук'янова, В. Малишев, О. Плахотник, К. Ситник), проблемам формування екологічної свідомості, екологічногомислення, екологічноїкуптури(О. Гордієнко, Н. Єфіменко, О. Король, О. Матеюк, А. Радей ), проблемам підготовки фахівця до екологовідповідної діяльності у закладах вищої освіти (Л. Білик, В. Онопрієнко, Т. Саєнко, І. Тимчук).

Розглядаючи екологічну освіту як базову складову екологічної політики держави, Т. Іванова акцентує на тому, що "стан збереження навколишнього природного середовища i раціональне використання природних ресурсів, ефективність виробництва перебувають у прямій залежності від розвитку освіти, вдосконалення нових освітніх технологій і підвищення екологоекономічного освітнього рівня населення" [3].

“Екологічне знання є основою для формування нової парадигми екологічного мислення та екологічної культури, стверджує А. Радей Проблема формування екологічного знання як ядра екологічної свідомості пов'язана зі встановленням нової екологічної парадигми, що заснована на гуманістичних засадах ставлення до природного середовища. Гуманізація екологічного знання щільно пов'язана 3 проблемою етичноекологічного імператива як гаранта гармонізації складових всередині системи, умовно називаної “природа суспільство" [7].

Актуальним є дослідження О. Матеюк, присвячене проблемі формування екологічної культури майбутніх економістів. Автор зазначає наступне: “Сьогодні вкрай важливо сформувати майбутньому економісту такий підхід до вирішення екологічних проблем, який би дозволив йому поглянути на світ природи, на його збереження з різних позицій: як представника світової цивілізації, громадянина країни, жителя своєї місцевості, професіонала. Екологічна освіта, що базується на "новій екологічній парадигмі", покликана сприяти формуванню екологічного мислення" [5, 97].

На думку О. Гордієнко та Н. Єфіменко: “Основним завданням сучасної екологічної освіти $є$ оснащення фахівців методологією різних методів екологічного менеджменту. Фахівець, що професійно мислить повинен використовувати різні методи екологічногоуправління природокористування, може розумно вирішувати виробничі завдання, моделювати економічні й екологічні ситуації, а також знаходити шляхи виходу з них. Тільки розвиваючи і формуючи творчий потенціал студентів, можна розраховувати на їх внугрішню готовність до вирішення складних технічних, технологічних, економічних і екологічних завдань" $[2,124]$.

Аналіз досліджень і публікацій з даної проблеми дозволяє зробити висновок, що проблема екологічної освіти є надзвичайно актуальною, а питання теорії та практики формування екологічної свідомості, екологічних знань студентів у процесі навчання за фахом потребують подальшого аналізу та висвітлення.

Мета статті - проаналізувати систему підготовки майбутніх менеджерів до екологічно виправданої професійної діяльності на засадах сталого розвитку.

Виклад основного матеріалу. Вища екологічна освіта спрямована на здобуття 
професійних екологічних знань відповідно до фаху. Згідно з Концепцією екологічної освіти програма підготовки фахівців повинна передбачити:

- здобуття відповідного обсягу теоретичних знань 3 екології, орієнтованих на майбутню галузеву діяльність;

- розвиток необхідного обсягу практичних екологічних знань в галузі охорони довкілля та раціонального природокористування, уміння самостійно аналізувати і моделювати екологічні ситуації з орієнтацією на управління ними;

- розвиток здатності оцінювати екологічні ситуації і здійснювати заходи по охороні довкілля з позицій сучасної екології, політики, економіки, законодавства;

- формування активної громадської позиції щодо вирішення проблем захисту довкілля [4].

Метою екологічної освіти майбутніх фахівців менеджменту $\epsilon$ підготовка до екологічно виправданої професійної діяльності на засадах сталого розвитку. Мета визначає завдання екологічної освіти студентів-менеджерів формування цілісного екологічного знання й мислення, необхідних для прийняття екологічнообгрунтованих управлінських рішень.

Отже, питання підготовки сучасного менеджера з екологічним мисленням, свідомістю, пов'язане, перш за все, із формуванням у нього здатності до раціонального та екологічно доцільного вирішення професійних завдань 3 урахуванням природоохоронних вимог, готовності приймати управлінські рішення, які відповідатимуть принципам сталого розвитку.

На розуміння майбутнім менеджером необхідності врахування екологічної ситуації при прийнятті управлінських рішень та оцінки екологічних ризиків діяльності підприємства, усвідомлення ним екологічної відповідальності за наслідки впливу виробничої та господарської діяльності на навколишнє середовище спрямований курс "Екологічний менеджмент". Дисципліна спрямована на формування у студентів системи знань і практичних навичок щодо розвитку системи екологічного менеджменту, аудиту.

"Екологічний менеджмент вивчає управлінські відносини в організації, які забезпечують эiї сталий розвиток, охорону навколишнього середовища, безпеку життєдіяльності людини, раціональне використання природних ресурсів і екологічну безпеку, спрямовану на реалізацію екологічних цілей і програм впливу на навколишнє середовище, а також формує знання екологічної стратегії розвиткусуспільства, управління природокористуванням іохороною природи" $[1,106]$.
Теоретична і практична підготовка до екологовідповідної діяльності базується на системі методологічних підходів, дидактичних принципів. В основу фахової підготовки студентів до роботи у системі екологічного менеджменту та аудиту покладено наступні методологічні підходи: аксіологічний, діяльнісний, компетентнісний, системний.

Аксіологічний підхід забезпечує формування у студентів розуміння того, що збереження довкілля та збалансоване природокористування $\epsilon$ важливою категорією в системі цінностей суспільства; сприяє формуванню позитивної мотивацій до діяльності на засадах сталого розвитку.

Діяльнісний підхід передбачає використання теоретичних знань для формування практичних вмінь та навичок щодо застосування принципів, методів, інтсрументів екологічного менеджменту та аудиту.

Компетентнісний підхід полягає в такій організації навчального процесу, коли поряд 3 засвоєнням необхідних екологічних знань та вмінь, формуються професійні компетентності майбутнього фахівця. У нашому випадку - це здатність приймати управлінські рішення відповідно до інтересів збереження довкілля та раціонального природокористування.

Системний підхід забезпечує оптимальне поєднання засобів, форм, методів, умов підготовки майбутніх менеджерів до ефективного застосування системи екологічного менеджменту.

Дидактичними принципами екологічної освіти майбутніх менеджерів є принцип безперервності екологічної освіти, науковості, доступності, зв' язку теорії з практикою, принцип професійного спрямування. Принцип безперервності екологічної освіти передбачає включення екологічної освіти в закладах вищої освіти в загальну систему екологічної освіти; принцип науковості забезпечує достовірність, наукову обгрунтованість фактів, інформації, знань, які студенти засвоюють в процесі навчання; принцип доступності полягає у тому, що в процесі підготовки майбутніх менеджерів враховують рівень розвитку студентів, дотримується правило: від простого до складного, від відомого - до невідомого; принцип зв'язку теорії з практикою забезпечує підкріплення отриманих теоретичних знань практичними вміннями та навиками; принцип професійного спрямування грунтується на тому, що зміст, методи, форми навчання визначаються і підбираються 3 врахуванням специфіки майбутньої професійної практичної діяльності, у нашому випадку - використання в 
управлінській діяльності методів екологічного менеджменту.

Зазначені методологічні підходи та дидактичні принципи взаємопов'язані і в сукупності забезпечують ефективність навчально-виховного процесу.

Курс “Екологічний менеджмент” спрямований на формування у майбутніх менеджерів спеціальних фахових знань, а також на формування відповідних цим знанням практичних вмінь. На лекціях студенти знайомляться 3 предметом, змістом і методами екологічного менеджменту, науково-методичними підходами до формування системи екологічного управління, вивчення проблематики ліцензування та оподаткування у розрізі екологічного менеджменту, екологічного аудиту тощо.

На практичних, семінарських заняттях студенти вчаться прогнозувати та моделювати еколого-безпечну майбутню професійну діяльність, застосовувати методи екологічного менеджменту, утверджуються у втіленні принципів сталого розвитку на практиці.

В процесі вивчення курсу “Екологічний менеджмент" застосовують наступні методи роботи (розповідь, бесіда, диспут, проблемні ситуації, тренінгові вправи, проектний метод, ділова гра; аналіз зразків екологічного управління та менеджменту різних підприємств тощо).

Засобами підготовки майбутніх менеджерів $\epsilon$ наукова, методична література, періодичні видання (підручники, посібники, довідники, журнали), дидактичні засоби (таблиці, презентації) тощо.

“До сьогодні екологічна освіта України продовжує базуватись на засадах підходу до природи, як до невичерпного ресурсу без врахування катастрофічних наслідків такого підходу. А ці наслідки вже призвели до незворотних змін і потребують докорінної перебудови підходів до формування загальних засад екологічної освіти. Екологічна освіта має базуватись на реаліях еколого-ресурсного потенціалу та розумінні наслідків “наших перемог над природою” [8]. Тому під час вивчення курсу "Екологічний менеджмент" необхідно формувати в студентів усвідомлення того, що довкіллям необхідно опікуватися, бути відповідальним за його збереження, дотримуватись вимог екологічної безпеки й що для цього необхідні відповідні знання, уміння, мотивації та зобов'язання як для індивідуальної, так і для колективної роботи.

Євроінтеграційні процеси вимагають оновлення екологічного законодавства України, врахування стандартів СС в екологічній сфері задля сталого розвитку та збереження довкілля для майбутніх поколінь. Тому сучасна педагогіка має враховувати соціальні реалії та потреби в процесі екологічної підготовки фахівців. Студентів необхідно знайомити 3 основними нормативноправовими актами України в сфері природокористування, законодавчо-регулюючою базою екологічного менеджменту, акцентувати на необхідності враховувати екологічні закони, закономірності, наукові принципи, що діють комплексно в біологічній, технологічній, економічній, соціальній сферах.

Щоб навчання було результативним, отримані теоретичні знання мають бути підкріплені практичними вміннями та навиками. Так, серед ефективних методів та форм навчальної роботи, які активізують екологічне мислення студентів та посилюють мотиваційну готовність до екологічно виправданої професійної діяльності на засадах сталого розвитку варто відзначити ігрові та проблемно-ситуаційні методи. Під час аналізу еколого-економічних, управлінських ситуацій, в ході ділових ігор студенти вчаться моделювати розв'язання різних професійних завдань, застосовувати принципи, інструменти екологічного менеджменту на практиці та приймати управлінські рішення з врахуванням екологічних факторів.

Висновки і пропозиції. Проведений аналіз системи підготовки майбутніх менеджерів до екологічно виправданої професійної діяльності на засадах сталого розвитку показав, що в закладах вищої освіти на формування екологічних знань, екологічної свідомості спрямований курс “Екологічний менеджмент”. Він забезпечує системну підготовку шляхом поєднання екологічної освіти та виховання, формує ціннісні орієнтації та екологічний стиль мислення майбутніх фахівців.

\section{ЛІТЕРАТУРА}

1. Білявська Ю. В. Екологічний менеджмент підприємства. Науковий журнал “Економіка України”. 2016. № 4 (653). С. 104-111.

2. Гордієнко О. І., Єфіменко Н. П. Актуальність формування і розвиток екологічного менеджменту у майбутніх інженерів-педагогів. Екологічний менеджмент : Зб. наук. пр. / За ред. В. А. Гайченка. Київ, 2006. 266 с., С. 124-129.

3. Іванова Т. В. Екологічна освіта як базова складова екологічної політики держави Вісник Національного авіаційного університету. Серія: Педагогіка, Психологія. URL: http://jrnl.nau.edu.ua/ index.php/VisnikPP/article/view/12553 (дата звернення: 27.03.2019). 
4. Концепція екологічної освіти України: Ухвала Колегії МОН України № 13/6-19 від 20.12.01 / URL: https://zakon.rada.gov.ua/rada/show/v6-1929001 (дата звернення: 14.03.2019).

5. Матеюк О. П. Формування екологічної культури майбутніх економістів як складової професійної підготовки на засадах сталого розвитку: дис. ...канд. пед. наук : 13.00.04. Хмельницький, 2008.238 с.

6. Олефіренко О. Екологічний менеджмент як основа сталого розвитку. Ефективність державного управління : Зб. наук. пр. 2013. Вип. 36. С. $82-89$.

7. Радей А. С. Екологічна свідомість і культура: теоретико-методологічний аспект. Вісник НТУУ “КПІ”. Філософія. Психологія. Педагогіка: збірник наукових праць, № 3(24). 2008. URL: http:/ /ela.kpi.ua/handle/123456789/8812 (дата звернення: 20.03.2019).

8. Резолюція учасників Всеукраїнського екологічного форуму “Екологічна освіта для сталого розвитку: проблеми, пошуки, інновації”. Київ, 2015 p. URL: https://nenc.gov.ua/wp-content/ uploads/2015/01/4-5-03-2015.pdf(дата звернення: 01.03.2019).

\section{REFERENCES}

1. Biliavska, Yu. V. (2016). Ekolohichnyi menedzhment pidpryiemstva [Environmental management of the enterprise]. Scientific journal “Economics of Ukraine”. Vol. 4 (653), pp. 104-111. [in Ukrainian].

2. Hordiienko, O. I. \& Yefimenko, N. P. (2006). Aktualnist formuvannia i rozvytok ekolohichnoho menedzhmentu u maibutnikh inzheneriv-pedahohiv [Actuality of the formation and development of environmental management of future engineersteachers]. Ecological Management: coll. of scientific works: by ed. V. A. Haichenka. Kyiv, pp. 124-129. [in Ukrainian].

3. Ivanova, T. V. Ekolohichna osvita yak bazova skladova ekolohichnoi polityky derzhavy [Ecological education as a basic component of the state environmental policy]. Bulletin of the National Aviation University. Series: Pedagogy, Psychology. Available at: http://jrnl.nau.edu.ua/index.php/ VisnikPP/article/view/12553 (Accessed 27 March 2019). [in Ukrainian].

4. Kontseptsiia ekolohichnoi osvity Ukrainy [Concept of ecological education of Ukraine]. Decision of the College MES of Ukraine. Available at: http://social-science.com.ua/article/416 (Accessed 14 March 2019). [in Ukrainian].

5. Mateiuk, O. P. (2008). Formuvannia ekolohichnoi kultury maibutnikh ekonomistiv iak skladovoi profesiinoi pidhotovky na zasadakh staloho rozvytku [Formation of ecological culture of future economists as a component of professional training on the principles of sustainable development]. Doctor's thesis. Khmelnytskyi, 238 p. [in Ukrainian].

6. Olefirenko, O. (2013). Ekolohichnyi menedzhment iak osnova staloho rozvytku [Environmental management as a basis for sustainable development]. Effectiveness of public administration: coll. of scientific works. Vol. 36, pp. 82-89. [in Ukrainian].

7. Radei, A. S. Ekolohichna svidomist i kultura: teoretyko-metodolohichnyi aspekt [Ecological consciousness and culture: theoretical and methodological aspects]. Bulletin of the NTUU "KPI”. Philosophy. Psychology. Pedagogy: a coll. of scientific works. Available at: http://ela.kpi.ua/ handle/123456789/8812 (Accessed 20 March 2019). [in Ukrainian].

8. Rezoliutsiia uchasnykiv Vseukrainskoho ekolohichnoho forumu "Ekolohichna osvita dlia staloho rozvytku: problemy, poshuky, innovatsii” (2015). [Resolution of the All-Ukrainian Ecological Forum "Ecological Education for Sustainable Development: Problems, Searches, Innovations" Participants]. Kyiv. Available at: https://nenc.gov.ua/wp-content/uploads/ 2015/01/4-5-03-2015.pdf(Accessed 01 March 2019). [in Ukrainian].

Стаття надійшла до редакції 11.03.2019

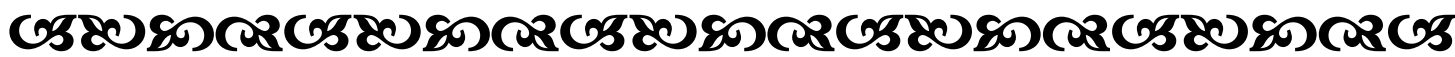

“Ефективний керівниккониентрується на можливостях а не на проблемах”.

Timep Dpyкер

австрійсъкий економіст, публіиист

“Безперервне навчання - мінімальна вимога для того, щоб досягти успіху в будь якiй сберi”.

Dенис Вейтлі американський оратор

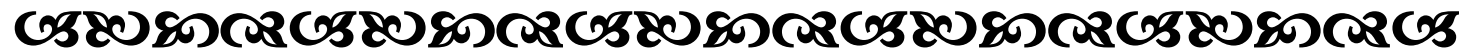

